\title{
Bacterial translocation and in vivo assessment of intestinal barrier permeability in rainbow trout (Oncorhynchus mykiss) with and without soyabean meal-induced inflammation
}

\author{
Peyman Mosberian-Tanha ${ }^{1}$, Margareth $\varnothing_{\text {verland }}{ }^{1}$, Thor Landsverk ${ }^{2}$, Felipe E. Reveco ${ }^{1}$, \\ Johan W. Schrama ${ }^{3}$, Andries J. Roem ${ }^{3}$, Jane W. Agger ${ }^{4}$ and Liv T. Mydland ${ }^{1} *$ \\ ${ }^{1}$ Department of Animal and Aquacultural Sciences, Norwegian University of Life Sciences, PO Box 5003, NO-1432 As, Norway \\ ${ }^{2}$ Department of Basic Sciences and Aquatic Medicine, Norwegian University of Life Sciences, N-0033 Oslo, Norway \\ ${ }^{3}$ Aquaculture and Fisheries Group, Wageningen Institute of Animal Sciences, PO Box 338, $6700 \mathrm{AH}$ Wageningen, The Netherlands \\ ${ }^{4}$ Department of Chemistry, Biotechnology and Food Science, Norwegian University of Life Sciences, PO Box 5003, NO-1432 As, Norway
}

(Received 15 January 2016 - Final revision received 11 February 2016 - Accepted 15 February 2016)

Journal of Nutritional Science (2016), vol. 5, e26, page 1 of 10

doi:10.1017/jns.2016.7

Abstract

The primary aim of this experiment was to evaluate the intestinal barrier permeability in vivo in rainbow trout (Oncorbynchus mykiss) fed increasing levels of soyabean meal (SBM). The relationship between SBM-induced enteritis (SBMIE) and the permeability markers was also investigated. Our results showed that the mean score of morphological parameters was significantly higher as a result of $37.5 \%$ SBM inclusion in the diet, while the scores of fish fed $25 \%$ SBM or lower were not different from those of the fish meal-fed controls $(P<0.05)$. SBMIE was found in the distal intestine (DI) in $18 \%$ of the fish (eleven of sixty): ten in the $37.5 \%$ SBM-fed group and one in the $25 \%$ SBM-fed group. Sugar markers in plasma showed large variation among individuals probably due to variation in feed intake. We found, however, a significant linear increase in the level of plasma D-lactate with increasing SBM inclusion level $(P<0 \cdot 0001)$. Plasma concentration of endotoxin was not significantly different in groups with or without SBMIE. Some individual fish showed high values of endotoxin in blood, but the same individuals did not show any bacterial translocation. Plasma bacterial DNA was detected in $28 \%$ of the fish with SBMIE, and $8 \%$ of non-SBMIE fish $(P=0 \cdot 07)$. Plasma concentration of D-lactate was significantly higher in fish with SBMIE $(P<0 \cdot 0001)$. To conclude, SBMIE in the DI of rainbow trout was associated with an increase in bacterial translocation and plasma D-lactate concentration, suggesting that these permeability markers can be used to evaluate intestinal permeability in vivo.

Key words: Rainbow trout: Soyabean meal: Enteritis: Intestinal permeability: Permeability markers

Inclusion of sustainable ingredients as substitutes of traditional fish meal (FM) in fish diet is crucial to ensure further growth in the aquaculture sector ${ }^{(1)}$. Plant protein ingredients can serve as potential alternatives to replace $\mathrm{FM}^{(2)}$. As a result, substitution of FM by these ingredients has been reported and discussed in several publications ${ }^{(3-5)}$. Plant proteins contain anti-nutritional factors which can cause nutritional and health issues in salmonid fish such as inflammatory response in the distal intestine (DI) and lowered macronutrient digestibility ${ }^{(6-8)}$. The most widely used plant protein in animal production is soyabean meal (SBM) ${ }^{(2)}$ which has also been studied in carnivorous fish. SBM, however, has shown to cause inflammation in the DI of salmonid fish, often referred to as SBM-induced enteritis (SBMIE) ${ }^{(7)}$, the cause of which is not yet fully known. SBMIE has been used as a model to study plant ingredient-induced enteropathy in salmonids ${ }^{(8,9)}$.

Abbreviations: DGGE, denaturing gradient gel electrophoresis; DI, distal intestine; FCR, feed conversion ratio; FM, fish meal; L:R, lactulose:L-rhamnose; S:R, sucralose: L-rhamnose; SBM, soyabean meal; SBMIE, soyabean meal-induced enteritis.

* Corresponding author: L. T. Mydland, email liv.mydland@nmbu.no 
The gastrointestinal tract acts as a barrier between the external and internal environments. The integrity of the gut barrier is crucial to maintain homeostasis, that is, to prevent pathogens or toxins from entering the bloodstream while maintaining nutrient absorption function ${ }^{(10,11)}$. The barrier function of the gut is supported by epithelial cells, mucus and tight junction proteins ${ }^{(12-14)}$. Increased gut permeability due to the loss of barrier function potentiates systemic absorption of pathogens and toxic molecules which has been shown to be associated with intestinal inflammation in mammals and fish ${ }^{(15,16)}$.

Epithelial permeability function has been assessed in mammals by in vitro methods such as transepithelial electrical resistance and in vivo tests such as transepithelial passage of sugar markers, endotoxins and D-lactate ${ }^{(13,14)}$. The in vivo methods are based on the assumption that microbes, large molecules and bacterial products cannot pass through the epithelial barrier and be absorbed in blood when the intestinal integrity is maintained $^{(14)}$. Urinary or plasma levels of orally administered sugars such as sucrose, mannitol, rhamnose, lactulose and sucralose have been used as markers in mammalian intestinal permeability evaluations ${ }^{(17,18)}$. In these studies the ratio of disaccharides to monosaccharides in samples are calculated and used to assess barrier function ${ }^{(18)}$. Degradability of sugar molecules in different regions of the gastrointestinal tract has led to region-specific permeability experiments ${ }^{(13)}$. For example, the lactulose:L-rhamnose ratio (L:R) has been used for small-intestinal permeability evaluation because lactulose is fermentable in the colon ${ }^{(19)}$. In humans, inflammatory bowel disease and coeliac disease are two examples of intestinal inflammation which have been shown to be associated with increased urinary levels of sugar markers ${ }^{(20,21)}$.

Blood or plasma measurement of bacteria and their products is another in vivo method used for the evaluation of bacterial translocation and intestinal permeability. Measurement of plasma endotoxin, D-lactate and detection of bacterial DNA using PCR-based methods have been used to assess the function of the intestinal barrier. Lipopolysaccharides are endotoxins which partially form the outer membrane of Gram-negative bacteria and are known to be toxic to humans and animals ${ }^{(22,23)}$. For quantitative measurement of endotoxin levels in plasma samples, the limulus amebocyte lysate assays (LAL), such as chromogenic LAL, have been widely used as a sensitive method $^{(24)}$. Intestinal inflammation has shown to be associated with increased endotoxin levels in the circulation which could be a result of epithelial barrier hyperpermeability ${ }^{(25,26)}$. Many bacteria in the gastrointestinal tract produce D-lactate which has been used as a permeability marker in humans and animals due to the fact that it cannot be metabolised by mammals ${ }^{(27-29)}$. In healthy individuals, a low concentration of D-lactate is found in plasma, but the level is known to increase as a result of increased intestinal permeability ${ }^{(14,30)}$. PCR is a sensitive method which has been used for the detection of bacterial DNA in blood to assess intestinal barrier function in a number of experiments ${ }^{(31-33)}$. PCR has proven to be more sensitive than conventional culture methods in detecting bacteria and it is also able to detect dead bacteria in samples ${ }^{(31,34)}$.

The effect of plant ingredients on intestinal barrier permeability and function is not yet fully understood in fish.
Experiments on intestinal barrier permeability in fish has been mainly based on in vitro and molecular studies such as studies of gene expression ${ }^{(35-38)}$. SBM or SBM-extracted alcohol-soluble substances are examples of dietary factors which have been shown to increase intestinal permeability in fish in vitro ${ }^{(15,39)}$ and alter morphology of brush borders leading to tight junction exposure to the luminal components ${ }^{(40)}$. To our knowledge, there is no information available on in vivo assessment of intestinal permeability in salmonids fed SBM. Thus, this experiment was designed to evaluate intestinal barrier permeability in vivo in rainbow trout fed with increasing levels of SBM by using plasma endotoxin, D-lactate, sugar molecules and detection of bacterial DNA as markers. Furthermore, the change in intestinal permeability was investigated in relation to SBMIE.

\section{Materials and methods}

\section{Fish husbandry and experimental diets}

The experiment was performed at the fish laboratory located at the Norwegian University of Life Sciences (Ås, Norway), which is an approved research facility by the Norwegian Animal Research Authority and operates in accordance with the Norwegian Regulations of 17 June 2008 no. 822: Regulations relating to Operation of Aquaculture Establishments (Aquaculture Operation Regulations). A total of 300 rainbow trout (Oncorbynchus mykiss) with mean initial body weight of $236 \mathrm{~g}$ were randomly allocated into twelve tanks. Each tank (300 litres) was supplied with recirculated fresh water at a flow rate of 7.5 litres $/ \mathrm{min}$ under continuous light. Water temperature ranged from 8 to $11^{\circ} \mathrm{C}$. Daily measurement of dissolved $\mathrm{O}_{2}$ levels was performed and kept above $8.0 \mathrm{mg} / \mathrm{l}$ in the outlet water. Four iso-energetic experimental diets were formulated and consisted of a FM-based control and three experimental diets containing SBM at levels of 12.5, 25 and $37.5 \%$ (Table 1). The total experimental period lasted for $31 \mathrm{~d}$, and a mixture of sugar markers, consisting of $10 \mathrm{~g}$ lactulose, $10 \mathrm{~g}$ sucralose and $5 \mathrm{~g}$ L-rhamnose (Sigma-Aldrich), was added per $\mathrm{kg}$ of each diet and fed during the last $3 \mathrm{~d}$. Fish were fed $30 \%$ in excess and uneaten feed was collected from the tank outlets after each feeding period. Feed preparation and daily feed intake calculations were performed as described in Øverland et al. ${ }^{(41)}$. The fish were fed until the time of sampling to avoid an empty intestine in fish used for analysis.

\section{Fish sampling}

On day 28, before the addition of sugar markers to the diets, nine fish per treatment (three fish/tank) were randomly selected and anaesthetised with Aquacalm (12 mg/l) for blood sampling. Blood samples were collected from the caudal vein in heparinised sterile syringes, transferred to Eppendorf tubes, and centrifuged ( $3000 \mathrm{~g}$ for $5 \mathrm{~min}$ ) to obtain plasma. The plasma was then stored at $-80^{\circ} \mathrm{C}$ for sugar marker analysis to determine any possible concentration of these molecules which was not due to the consumption of sugar marker-containing diets. After blood sampling fish were killed 
Table 1. Formulation and chemical composition (as-is) of fish meal (FM) and experimental diets

\begin{tabular}{|c|c|c|c|c|}
\hline & FM & $\begin{array}{c}\text { SBM } 12 \cdot 5 \\
\%\end{array}$ & $\begin{array}{c}\text { SBM } 25 \\
\%\end{array}$ & $\begin{array}{c}\text { SBM } 37.5 \\
\%\end{array}$ \\
\hline \multicolumn{5}{|l|}{ Ingredients (g/kg, as-fed) } \\
\hline Fish meal $^{*}$ & $620 \cdot 0$ & $500 \cdot 0$ & $370 \cdot 0$ & 229.0 \\
\hline Soyabean meal† & - & $125 \cdot 0$ & $250 \cdot 0$ & $375 \cdot 0$ \\
\hline Fish oilł & 183.9 & 178.9 & 183.9 & 199.9 \\
\hline $\begin{array}{l}\text { Gelatinised potato } \\
\text { starch§ }\end{array}$ & $110 \cdot 0$ & $110 \cdot 0$ & $110 \cdot 0$ & $110 \cdot 0$ \\
\hline Gelatin $\|$ & $80 \cdot 0$ & $80 \cdot 0$ & 80.0 & $80 \cdot 0$ \\
\hline Premixף & $6 \cdot 0$ & $6 \cdot 0$ & $6 \cdot 0$ & $6 \cdot 0$ \\
\hline $\mathrm{Y}_{2} \mathrm{O}_{3}{ }^{* *}$ & 0.1 & 0.1 & 0.1 & 0.1 \\
\hline \multicolumn{5}{|l|}{ Analysed content } \\
\hline DM & 950 & 935 & 927 & 944 \\
\hline Crude protein (g/kg DM) & 512 & 489 & 462 & 432 \\
\hline Crude lipid (g/kg DM) & 240 & 229 & 256 & 227 \\
\hline Starch $(g / k g ~ D M)$ & 112 & 115 & 108 & 116 \\
\hline Ash (g/kg DM) & 109 & 95 & 83 & 69 \\
\hline Gross energy (MJ/kg DM) & 23.1 & $23 \cdot 0$ & $23 \cdot 2$ & $23 \cdot 2$ \\
\hline
\end{tabular}

SBM, soyabean meal.

* NorseaMink.

† Denofa.

‡ Skretting Norway.

$\S$ Lygel F 60, Lyckeby Culinar AB

$\|$ Rousselot $^{\mathrm{TM}} 250$ PS, Rousselot SAS.

IProvided the following (per kg diet): Ca $1.2 \mathrm{~g}, \mathrm{Mn}_{2} \mathrm{SO}_{4} 14.7 \mathrm{mg}, \mathrm{ZnSO}_{4} 117 \mathrm{mg}$, $\mathrm{CuSO}_{4} 4.90 \mathrm{mg}, \mathrm{CoSO}_{4} 980 \mu \mathrm{g}, \mathrm{Ca}\left(\mathrm{IO}_{3}\right)_{2} 3.6 \mathrm{mg}$, retinol $2450 \mathrm{IU}$, cholecalciferol $1470 \mathrm{IU}$, tocopherol $196 \mathrm{mg}$, menadione $9.80 \mathrm{mg}$, thiamine $14.7 \mathrm{mg}$, riboflavin $24.5 \mathrm{mg}$, pyridoxine $14.7 \mathrm{mg}$, cobalamine $19.6 \mu \mathrm{g}$, pantothenic acid $29.4 \mathrm{mg}$, folic acid $4.90 \mathrm{mg}$, niacin $73.5 \mathrm{mg}$, biotin $245 \mu \mathrm{g}$, vitamin C 1.75 (Rovimix $^{\circledR}$ Stay-C $^{\circledR} 35$, DSM Nutritional Products), AS Norsk Mineralnæring.

${ }^{* *}$ Di-yttrium trioxide $\left(\mathrm{Y}_{2} \mathrm{O}_{3}\right)$ (Metal Rare Earth, Ltd).

by a sharp blow to the head. At the end of the experiment and after feeding sugar-containing diets, five fish per tank were individually weighed and anaesthetised with Finquel $(60 \mathrm{mg} / \mathrm{l})$ prior to blood sampling, as described above. The anaesthetised fish were killed by a sharp blow to the head prior to dissection. Digesta samples from the DI were collected by carefully scraping with a sterile spatula into sterile containers, and stored on dry ice until transfer to $-80^{\circ} \mathrm{C}$. Tissue samples were also taken from the DI of each of the five fish and cut lengthways for morphological evaluation and fixed in neutral buffered formalin (4\% formaldehyde) for $48 \mathrm{~h}$ and then dehydrated in 70

$\%$ ethanol before embedding in paraffin following standard routines.

\section{Chemical analysis}

Diets were analysed for $\mathrm{DM}$ by drying at $105^{\circ} \mathrm{C}$ to constant weight, ash by incineration at $550^{\circ} \mathrm{C}$ overnight, crude protein by the Kjeldahl method $(\mathrm{N} \times 6 \cdot 25)$, crude fat by $\mathrm{HCl}$ hydrolysis followed by diethyl ether extraction, starch by $\alpha$-amylase and amyloglucosidase hydrolysis and gross energy by bomb calorimetry (Parr 1271 bomb calorimeter; Parr).

\section{Histology}

Dehydrated DI tissues were embedded in paraffin and stained by haematoxylin and eosin (H\&E) following a standard procedure. Blinded evaluation of four morphological parameters (Table 2) was performed on each tissue. A score was given
Table 2. Scoring system used to evaluate the degree of morphological changes in the distal intestine of soyabean meal-fed rainbow trout (Oncorhynchus mykiss)

\begin{tabular}{lll}
\hline Parameters & $\begin{array}{l}\text { Score } \\
\text { range }\end{array}$ & \multicolumn{1}{c}{ Description } \\
\hline Lamina propria & $0-2$ & $\begin{array}{l}\text { Leucocyte (e.g. lymphocyte, } \\
\text { granulocytes and eosinophilic granular } \\
\text { cells) infiltration and accumulation in the } \\
\text { lamina propria }\end{array}$ \\
$\begin{array}{l}\text { Epithelial } \\
\text { changes }\end{array}$ & $0-2$ & $\begin{array}{l}\text { Reduced supranuclear vacuolisation } \\
\text { Reduced height of epithelial cells } \\
\text { Increased cytoplasmic basophilia } \\
\text { Otrophy }\end{array}$ \\
Oedema & $0-2$ & $\begin{array}{l}\text { Shortening of the intestinal folds } \\
\text { Accumulation of fluid in the lamina } \\
\text { propria }\end{array}$ \\
\hline
\end{tabular}

to each parameter which ranged from 0 (no morphological change) to 2 (extreme changes). Scores of 0.5 and 1 were given to very slight changes (assessed as normal morphology) and mild changes, respectively. Based on this protocol at least a score of 1 should be given to the lamina propria, epithelial changes and atrophy to confirm occurrence of SBMIE. The total histological score was calculated by taking the average of the scores of the parameters to express the degree of SBMIE.

\section{DNA extraction}

Genomic DNA was extracted from plasma with the QIAamp DNA Blood Mini Kit (Qiagen) according to the manufacturer's protocol. Extracted DNA was then quantified and the purity was measured with a NanoDrop ${ }^{\mathrm{TM}} 8000$ spectrophotometer (Thermo Scientific) before it was stored at $-20^{\circ} \mathrm{C}$ for further analysis.

\section{Nested PCR protocol}

Amplification of $16 \mathrm{~S}$ rRNA genes from bacteria was performed using universal bacterial primers in a nested PCR. Primary amplification reactions were performed using primers 357F (5'-CCT AGG GGA GGC AGC AG-3') and 1369R $5^{\prime}$-GCCCGGGAACGTATTCACCG-3') in a $25 \mu \mathrm{l}$ reaction mixture containing $500 \mathrm{~nm}$ of each of the primers, $90 \mathrm{ng}$ of DNA template, $1 \times$ reaction buffer, $1.75 \mathrm{mM}-\mathrm{MgCl}_{2}, 300 \mu \mathrm{M}$ of each deoxyribonucleotide triphosphate (dNTP), 1.25 U Platinum $^{\circledR}$ Taq DNA polymerase (Invitrogen) and $0 \cdot 1 \%$ bovine serum albumin. Negative controls (DNA-free water) were included in all sets of PCR reactions to provide a contamination check. Reaction mixtures were subjected to the following cycling conditions: $94^{\circ} \mathrm{C}$ for $4 \mathrm{~min}$ then $59^{\circ} \mathrm{C}$ for $60 \mathrm{~s}$ and $72^{\circ} \mathrm{C}$ for $90 \mathrm{~s}$ followed by seven cycles of touch down PCR $\left(30 \mathrm{~s}\right.$ at $94^{\circ} \mathrm{C}, 30 \mathrm{~s}$ with $1{ }^{\circ} \mathrm{C} /$ cycle decrement from $59^{\circ} \mathrm{C}$ and $1 \mathrm{~min}$ at $72^{\circ} \mathrm{C}$ ). This was further followed by thirty cycles of $94^{\circ} \mathrm{C}$ for $30 \mathrm{~s}, 53^{\circ} \mathrm{C}$ for $30 \mathrm{~s}$ and $72^{\circ} \mathrm{C}$ for $90 \mathrm{~s}$ with a final extension step of $10 \mathrm{~min}$ at $72^{\circ} \mathrm{C}$. The secondary (nested) PCR was conducted using primers 357F (5'-CCT AGG GGA GGC AGC AG-3') containing a 40-bp GC clamp at the $5^{\prime}$ end and 519R (5'-ATT ACC GCG GCK GCT GG-3') in a 
$50 \mu \mathrm{l}$ reaction mixture for amplification of the $\mathrm{V} 3$ region of the bacterial $16 \mathrm{~S}$ rRNA genes. Nested PCR reaction mixtures contained: $200 \mu \mathrm{M}$ of each dNTP, $1.75 \mathrm{~mm}-\mathrm{MgCl}_{2}, 500 \mathrm{~nm}$ of each primer, $1 \times$ PCR buffer, $1.25 \mathrm{U}$ Platinum ${ }^{\circledR}$ Taq DNA polymerase (Invitrogen) and PCR products from the first round. A re-amplified negative control from the first-round PCR and a new negative control using water were also included. PCR conditions were as follows: $4 \mathrm{~min}$ at $94^{\circ} \mathrm{C}, 1.5 \mathrm{~min}$ at $64^{\circ} \mathrm{C}$ and $1.5 \mathrm{~min}$ at $72^{\circ} \mathrm{C}$ followed by seven cycles of touchdown PCR $\left(30 \mathrm{~s}\right.$ at $94^{\circ} \mathrm{C}, 30 \mathrm{~s}$ with an $1^{\circ} \mathrm{C} /$ cycle decrement from $64^{\circ} \mathrm{C}$ and $60 \mathrm{~s}$ at $72^{\circ} \mathrm{C}$ ) and followed by twenty-seven cycles of $45 \mathrm{~s}$ at $94^{\circ} \mathrm{C}, 45 \mathrm{~s}$ at $58^{\circ} \mathrm{C}, 60 \mathrm{~s}$ at $72^{\circ} \mathrm{C}$, and a final extension step of $10 \mathrm{~min}$ at $72^{\circ} \mathrm{C}$. To confirm successful amplification, $8 \mu \mathrm{l}$ of PCR products from each amplification step were analysed by gel electrophoresis (1.5\% agarose, stained with RedSafe ${ }^{\mathrm{TM}}$ Nucleic Acid Staining Solution from iNtRON Biotechnology, Inc.), and images were taken using the Gel Doc XR System (Bio-Rad Laboratories).

\section{Denaturing gradient gel electrophoresis analysis}

Denaturing gradient gel electrophoresis (DGGE) was performed to separate PCR products of $16 \mathrm{~S}$ rRNA genes. Polyacrylamide gels $(7.5 \%(\mathrm{w} / \mathrm{v})$ acrylamide) were made according to the manufacturer's instructions and were run on an Ingeny PhorU apparatus (Ingeny International BV) in a $0.5 \times$ TAE buffer (containing Tris base, acetic acid and EDTA). Denaturing gradients ranged from 42 to $58 \%$ (where $100 \%$ is defined as $7 \mathrm{M}$-urea and $40 \%(\mathrm{v} / \mathrm{v})$ formamide). Electrophoresis was performed at $75 \mathrm{~V}$ for $16 \mathrm{~h}$ at $60^{\circ} \mathrm{C}$ and gels were stained with SYBR Gold nucleic acid gel stain (Invitrogen) in $1 \times$ TAE for $10 \mathrm{~min}$ and photographed with Gel Doc XR System (Bio-Rad Laboratories).

\section{Denaturing gradient gel electrophoresis band sequencing}

Selected DGGE bands were excised from the gel with sterile pipette tips. Each piece was then transferred into $50 \mu \mathrm{l}$ of sterile water and eluted overnight at $4^{\circ} \mathrm{C}$. Eluted DNA $(3 \mu \mathrm{l})$ was subject to re-amplification applying the secondary (nested) PCR conditions as described previously, but with the following changes: eighteen cycles of PCR using $357 \mathrm{~F}$ primer without the GC clamp and the volume of reaction was $25 \mu \mathrm{l}$. Amplification products were visualised as described previously prior to purification using the MultiScreen 96-well filtration plate (Millipore). Sequencing was carried out using the BigDye ${ }^{\circledR}$ Terminator v3.1 Cycle Sequencing Kit, 357F and 519R primers on an ABI 3730 DNA analyser (Applied Biosystems). The BLAST (Basic Local Alignment Search Tool) program was used to search for the species with the closest known relationship with the $16 \mathrm{~S}$ rRNA gene sequences.

\section{Biochemical assays}

Endotoxin concentration in plasma samples was measured using ToxinSensor ${ }^{\mathrm{TM}}$ Chromogenic LAL Endotoxin Assay Kit (GenScript) under sterile conditions. The plasma samples were diluted at 1:1 (v/v) in endotoxin-free water and heated to $80^{\circ} \mathrm{C}$ for $10 \mathrm{~min}$ to remove non-specific endotoxin inhibitors. Endotoxin levels in samples were calculated from a standard curve of known endotoxin concentrations according to the manufacturer's instructions. Heparinised plasma was deproteinised by centrifugation through $10 \mathrm{~K}$ spin columns before the D-lactate concentration was measured using a commercial kit (D-lactate colorimetric assay; Sigma-Aldrich). The absorbance at $450 \mathrm{~nm}$ was read on a Wallac Victor 3 Multi-well Plate Reader (Perkin Elmer). D-Lactate concentration in distal intestinal content was determined using the same kit. In brief, an accurately weighed $200 \mathrm{mg}$ sample of digesta was mixed well with two volumes $(400 \mu \mathrm{l})$ of the D-lactate assay buffer. The digesta suspension was centrifuged through $10 \mathrm{~K}$ spin columns and the D-lactate concentration was assayed in 1:5 dilutions of the intestinal filtrate.

\section{Plasma analysis of sugar markers}

Plasma was filtrated by centrifugation through a $10 \mathrm{~K}$ spin column and diluted 1:1 with water before analysis by highperformance anion exchange chromatography (HPAEC) using a Dionex ICS3000 connected to a CarboPac PA1 column $\left(2 \times 250 \mathrm{~mm}^{2}\right)$ equipped with a guard of the same type $\left(2 \times 50 \mathrm{~mm}^{2}\right)$ (Dionex). The HPAEC system was operated with a flow rate of $0.25 \mathrm{ml} / \mathrm{min}$. Start eluent conditions was $10 \%$ eluent A $(0 \cdot 1 \mathrm{M}-\mathrm{NaOH})$ and $90 \%$ eluent C (MQwater) over $5 \mathrm{~min}$, then $100 \% \mathrm{~A}$ for $9 \mathrm{~min}$, from 14 to 19 min an increase in eluent $\mathrm{B}(0.1 \mathrm{M}-\mathrm{NaOH}+1 \mathrm{M}-\mathrm{NaOAc})$ from 0 to $50 \%$, along with a decrease in eluent A from 100 to $50 \%$, and thereafter back to $10 \%$ eluent A for $25 \mathrm{~min}$. Eluted sugar markers (L-rhamnose, lactulose, sucralose) were monitored by the pulsed amperometric detector fitted with disposable gold working electrodes to increase the sensitivity, chromatograms were recorded using Chromeleon software (Dionex), and quantification was performed using known external standards at multiple concentrations.

\section{Calculations and statistics}

Specific growth rate (SGR) of fish was calculated according to the following equation:

$$
\begin{aligned}
\text { SGR }= & 100 \\
& \times[\ln (\text { final body weight })-\ln (\text { initial BW })] / \text { days fed. }
\end{aligned}
$$

Feed conversion ratio (FCR) was calculated as:

$$
\mathrm{FCR}=\text { feed intake }(\mathrm{g}, \mathrm{DM}) / \text { fish weight gain }(\mathrm{g}) \text {. }
$$

Daily feed intake per fish was calculated on a DM basis as:

Feed intake(g, DM) over the experimental period/days fed.

Data were analysed by a one-way ANOVA using the general linear model (PROC GLM) and, when appropriate, by the $\chi^{2}$ test in SAS 9.4 (SAS Institute, Inc.). Tukey's honestly significant difference (HSD) test was performed for post hoc analysis. In addition, orthogonal contrasts for linear, quadratic and 
Table 3. Feed intake and growth performance of rainbow trout (Oncorhynchus mykiss) fed the experimental diets for $31 \mathrm{~d}$ (Mean values with pooled standard errors; $n 3$ )

\begin{tabular}{|c|c|c|c|c|c|c|}
\hline & FM & SBM $12.5 \%$ & SBM $25 \%$ & SBM $37.5 \%$ & SEM & $P$ \\
\hline Initial weight (g) & 235.8 & $236 \cdot 2$ & $235 \cdot 2$ & $235 \cdot 2$ & 2.51 & 0.91 \\
\hline Final weight $(\mathrm{g})$ & 334.3 & 327.9 & $344 \cdot 2$ & 330.5 & $9 \cdot 13$ & 0.13 \\
\hline Specific growth rate (\%) & 1.1 & 1.1 & 1.2 & 1.1 & 0.11 & 0.14 \\
\hline Feed intake $(g / d)$ & $2 \cdot 77^{a}$ & $2 \cdot 23^{a, b}$ & $2 \cdot 47^{\mathrm{a}, \mathrm{b}}$ & $2 \cdot 16^{\mathrm{b}}$ & 0.263 & 0.04 \\
\hline Feed conversion ratio & $0.87^{a}$ & $0.75^{\mathrm{b}}$ & $0.70^{\mathrm{b}}$ & $0.70^{\mathrm{b}}$ & 0.021 & $<0.0001$ \\
\hline
\end{tabular}

FM, fish meal; SBM, soyabean meal.

a,b Mean values within a row with unlike superscript letters were significantly different $(P<0.05)$.

cubic effects of the diets were determined using the ESTIMATE statement in PROC GLM. The OR was calculated (PROC LOGISITIC) as the ratio of the odds of bacterial translocation (PCR-positive) when SBMIE was present to the odds of bacterial translocation when SBMIE was absent. Data from histological evaluation and plasma lactulose and DNA level were not normally distributed after $\log 10$-transformation; and thus the analysis was performed using a non-parametric Kruskal-Wallis test by ranks followed by the Wilcoxon ranksum test. The level of significance was set at $P<0 \cdot 05$.

\section{Results}

\section{Growth rate and feed conversion}

Feed intake, growth rate and FCR are given in Table 3. There was a significant reduction in feed intake with the inclusion of $37.5 \%$ SBM in the diet compared with the FM diet $(P=0.04)$. Adding SBM to the diets had a significant effect on FCR $(P<$ 0.001). Fish fed the FM control diet had significantly higher FCR than those fed SBM-containing diets. Fish fed the $37.5 \%$ SBM diet had the lowest FCR, while the fish fed the $25 \%$ SBM diet had lower FCR than those fed the $12.5 \%$ SBM diet. There were no differences among the diets for final weight and specific growth rate (SGR).

\section{Morphological evaluation of the distal intestine}

The mean scoring of morphological parameters is shown in Fig. 1. Diets containing 12.5 and $25 \%$ SBM showed minor morphological changes, but were not statistically different from the FM control diet. Fish fed the 37.5\% SBM diet showed significantly increased changes in all morphological parameters $(P<0 \cdot 05)$. These changes were characterised by reduced supranuclear vacuoles and height of epithelial cells, reduced height of intestinal folds (atrophy) and widening of the lamina propria due to oedema and increased numbers of leucocytes (Table 2; Fig. 2). Histological evaluation revealed SBMIE in ten fish with varying degrees of morphological changes from the group fed $37.5 \%$ SBM and in one fish displaying a moderate SBMIE from the group fed $25 \%$ SBM.

\section{PCR-denaturing gradient gel electrophoresis analysis}

A total number of seven plasma samples were positive for bacterial 16S rDNA detection. DGGE analysis of the PCR products from these samples is presented in Fig. 3. The results from sequence analysis of excised bands from the DGGE gel are shown in Table 4. There was a total number of fourteen bands sequenced, of which four were short sequences (138-141 bp) and represented unspecific amplification (not shown), six
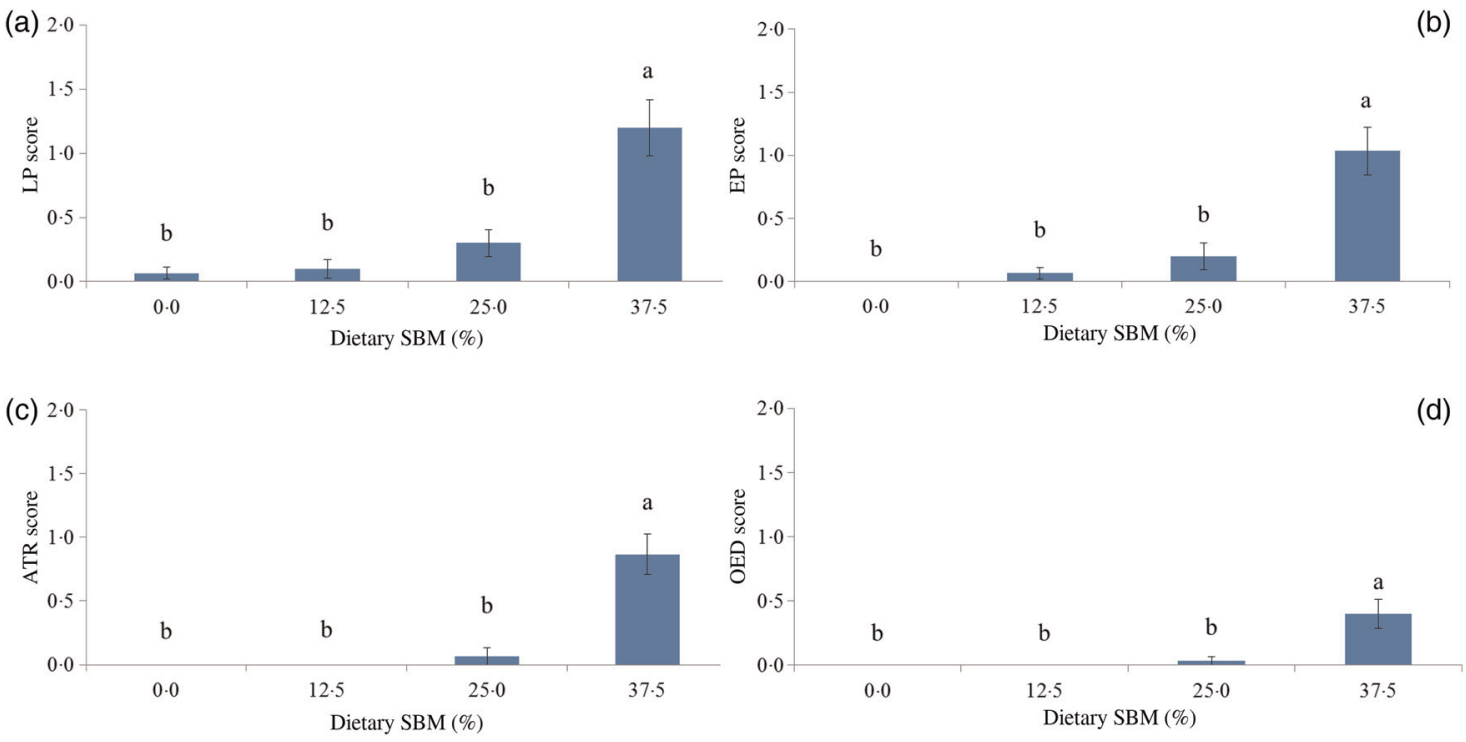

Fig. 1. Morphological evaluation of the distal intestine of rainbow trout (Oncorhynchus mykiss) fed a fish meal-based diet and three experimental diets containing soyabean meal (SBM) at levels of 12.5, 25 and $37.5 \%$. Changes in the leucocyte infiltrates in the lamina propria and submucosa (LP) (a); changes in the epithelium $(E P)$ (b); atrophy of the intestinal folds (ATR) (c); and accumulation of protein-rich fluid in the lamina propria defined as oedema (OED) (d). Values are means ( $n$ 15), with standard errors represented by vertical bars. ${ }^{\mathrm{a}, \mathrm{b}}$ Mean values with unlike letters were significantly different $(P<0.05)$. 

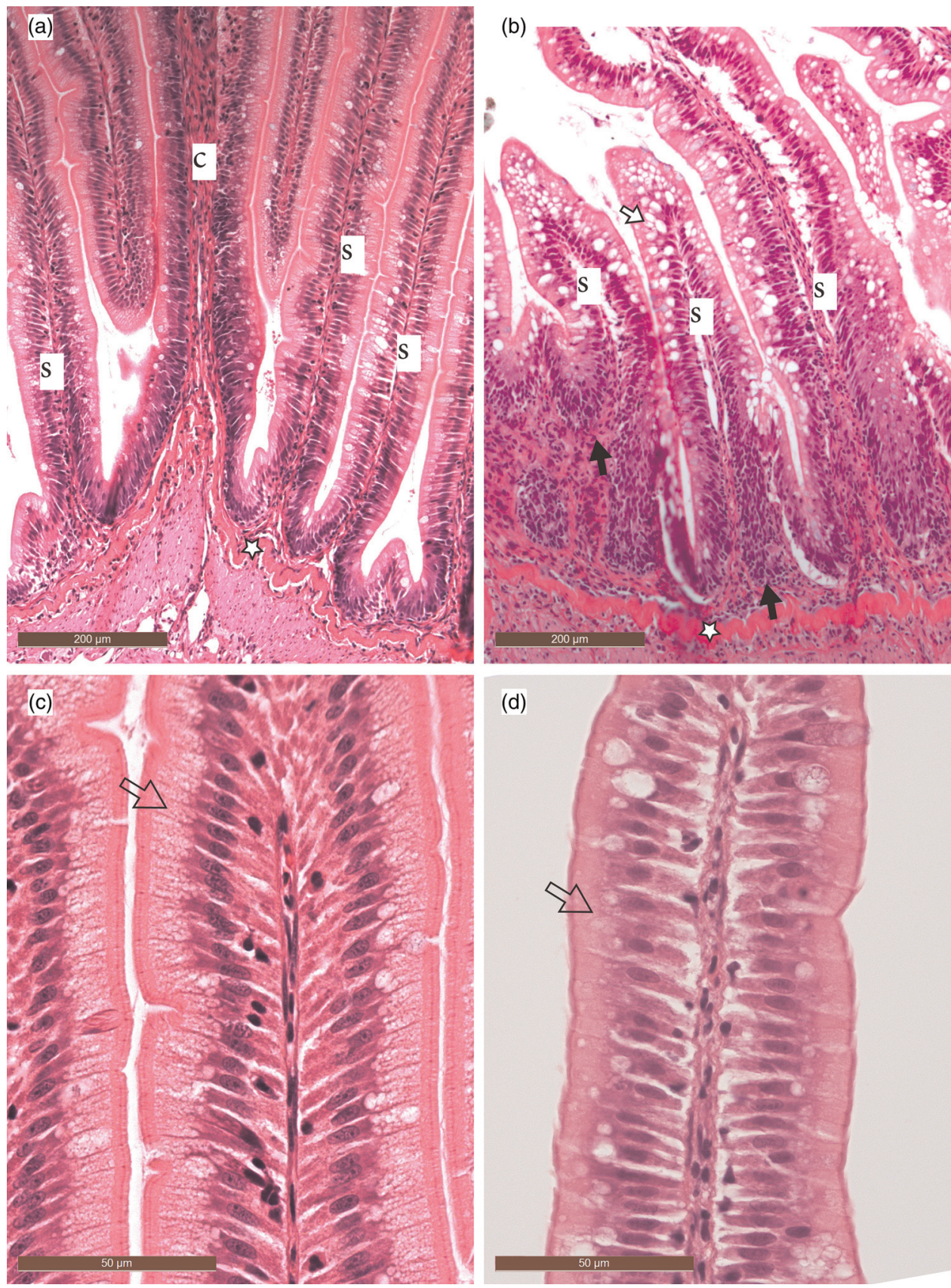

Fig. 2. Morphology of the distal intestine in rainbow trout (Oncorhynchus mykiss) stained with haematoxylin and eosin (H\&E) at low and high magnifications, respectively. Bars indicate the actual magnification. (a) Low magnification: fish meal control (non-soyabean meal-induced enteritis; non-SBMIE) - a normal intestine without subepithelial infiltrates of inflammatory leucocytes and slender simple (s) and complex (c) folds outlined by regular, high and finely vacuolated columnar epithelial cells. (b) Low magnification: soyabean meal $37.5 \%$ (SBMIE) - an inflamed intestine with atrophy of complex and simple folds and heavy infiltration of the subepithelial intestinal mucosa (black arrows) with inflammatory leucocytes and proliferation of fibroblasts, indicating a subacute state of inflammation. Note the many large, clear vacuoles in the epithelium (white arrow) which is probably due to the proliferation of goblet cells. The point stars on (a) and (b) indicate the stratum compactum. (c) High magnification: fish meal control (non-SBMIE) - a normal, high columnar epithelium with a finely vacuolated supranuclear cytoplasm (arrow) and a distinct brush border. (d) High magnification: soyabean meal $37.5 \%$ (SBMIE) - the epithelial cells have a denser cytoplasm (arrow), are lower in height and lack the finely vacuolated supranuclear zone seen in the normal tissue, although some clear and quite large intracytoplasmic vacuoles can be seen, probably due to the presence of goblet cells. The brush border is less distinct compared with the control.

represented Staphylococcus spp., while the remaining four bands were identified by BLAST (Basic Local Alignment Search Tool) as different Escherichia coli strains.

\section{Plasma levels of intestinal permeability markers}

Increasing dietary SBM inclusion resulted in non-significant changes in plasma endotoxin and total genomic DNA concentration (Table 5). None of the sugar markers could be detected in plasma from fish fed control and experimental diets on day 28 before the addition of dietary sugar markers. Variation in plasma sugar marker concentration was generally large among individuals; however, the variation was found to be somewhat lower for L-rhamnose (Table 5). Plasma sucralose levels were below the detection limit in many individuals and for all fish fed the 12.5 and $25 \%$ SBM diets. The plasma 


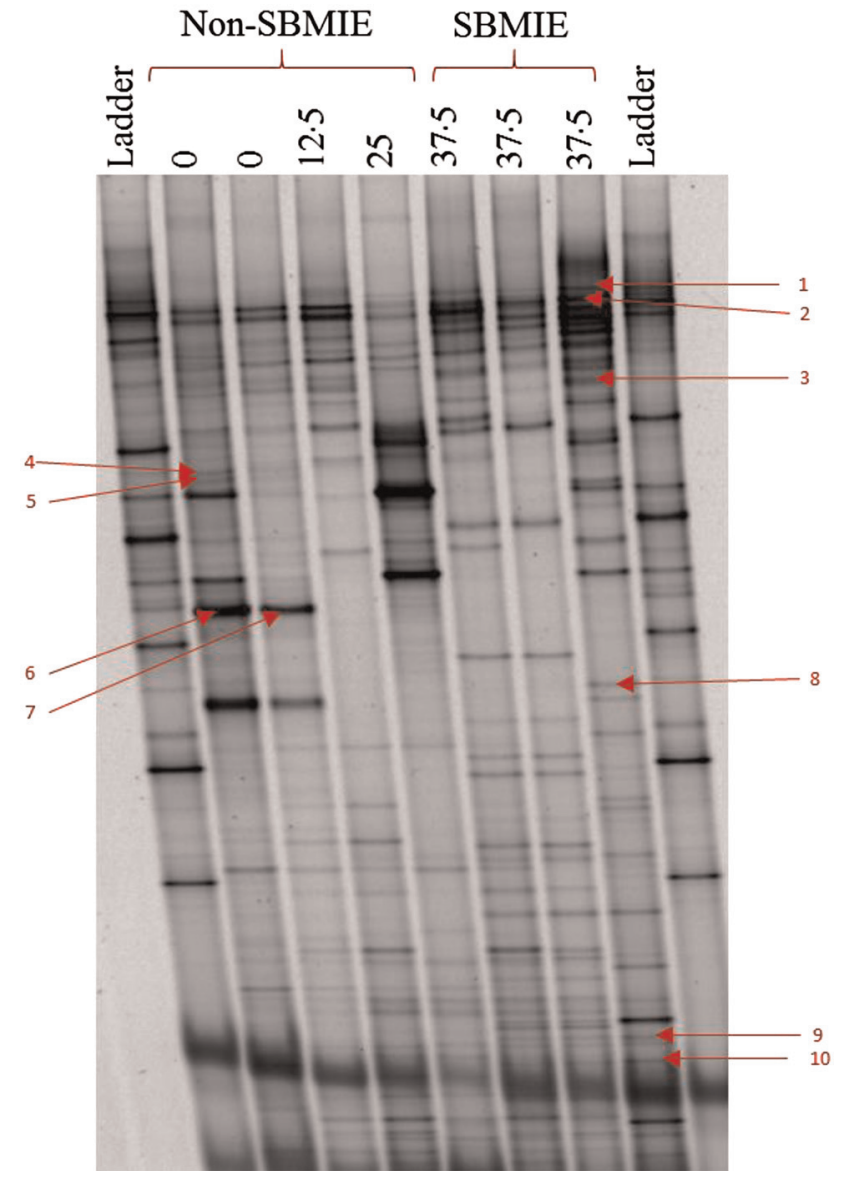

Fig. 3. Denaturing gradient gel electrophoresis (DGGE) profile of $16 \mathrm{~S}$ rDNA amplicons from the plasma of PCR positive rainbow trout (Oncorhynchus mykiss) fed diets with different soyabean meal (SBM) inclusion levels: 0, 12.5, 25 and $37.5 \%$. Bands 1-10 are excised DGGE bands used for sequence analysis. See Table 4 for details of each band's identification. SBMIE, SBM-induced enteritis.

levels of sucralose were not significantly different between FM- and 37.5\% SBM-fed fish. Plasma L-rhamnose levels were, however, significantly reduced in the group fed $37.5 \%$ $\operatorname{SBM}(P=0 \cdot 01)$. The variation was more prominent for lactulose and the plasma level of this sugar was not significantly different between FM-fed and 37.5 \% SBM-fed fish. Plasma L:R and sucralose:L-rhamnose (S:R) ratios in 37.5\% SBM-fed fish were not different from those in the control FM fish. Mean plasma D-lactate concentration was significantly higher in
$37.5 \%$ SBM-fed fish compared with the other groups $(P<$ 0.0001) (Table 5). The ESTIMATE statement revealed a linear increase in the plasma level of D-lactate with increasing level of SBM inclusion in the diet $(P<0.0001)$ while no linear, quadratic and cubic effects were observed for other permeability markers.

\section{Relationship between soyabean meal-induced enteritis, plasma permeability markers and PCR}

Differences in plasma endotoxin and genomic DNA concentration were found to be insignificant between SBMIE and non-SBMIE fish (Table 6). Three of eleven fish with SBMIE were shown to be PCR-positive (28\%) while this rate tended to be lower in non-SBMIE group, with only four of forty-nine $(8 \%)$ being PCR-positive $(P=0 \cdot 07)$. Three of seven PCR-positive fish (43\%) had also SBMIE while this ratio was only eight of fifty-three $(15 \%)$ in PCR-negative fish $(P=0.074)$ (Table 6$)$. The OR of positive PCR in fish with SBMIE was 4.5 (95\% CI 1.92-10.34) relative to the non-SBMIE fish $(P=0 \cdot 0005)$. The plasma L:R ratio was found to be higher in fish with SBMIE than that in non-SBMIE fish, but variation was high in this category (Table 6). Plasma L-rhamnose was, however, reduced in the SBMIE group $(P=0 \cdot 03)$. Fish with SBMIE demonstrated a higher plasma D-lactate level than non-SBMIE fish $(P<$ $0 \cdot 05)$. A positive but weak correlation was also found between the plasma level of D-lactate and degree of SBMIE ( $n$ 60, F = 24.6, $\left.r^{2} 0 \cdot 30, P<0 \cdot 001\right)$.

\section{Discussion}

The growth of fish fed increasing levels of SBM was comparable with that of the fish fed FM, as the SGR did not change in response to SBM inclusion. FCR gradually decreased as a result of increased SBM inclusion, which is not consistent with previous studies ${ }^{(42,43)}$. Lower FCR in this experiment may be due to the lower feed consumption by SBM-fed fish or a reduced passage rate of the feed and thus increasing the time for nutrient uptake in these fish. While increased inflammatory response was evident in the group fed $37.5 \%$ SBM, no adverse effect was observed on fish growth, which is in accordance with previous studies ${ }^{(44)}$. Moreover, the histological evaluation revealed a moderate degree of inflammation in fish fed

Table 4. Identification of denaturing gradient gel electrophoresis bands obtained from plasma based on 16S rDNA sequencing of the V3 region

\begin{tabular}{|c|c|c|c|c|}
\hline Band no. & Sequence length (bp) & Identification by BLAST & Homology (\%) & GenBank accession no. \\
\hline 1 & 161 & Staphylococcus sp. ECBMB15 & 100 & KJ425241.1 \\
\hline 2 & 161 & Staphylococcus sp. ECBMB11 & 100 & KJ425241.1 \\
\hline 3 & 161 & Staphylococcus cohnii strain BDA10 & 94 & HQ641334.1 \\
\hline 4 & 161 & Escherichia coli strain E417-1 & 99 & KJ477010.1 \\
\hline 5 & 163 & Escherichia coli strain G3T64 & 94 & GU646103.1 \\
\hline 6 & 161 & Escherichia coli strain E417-1 & 99 & KJ477010.1 \\
\hline 7 & 161 & Escherichia coli strain E417-1 & 99 & KJ477010.1 \\
\hline 8 & 162 & Staphylococcus sp. ECBMB15 & 97 & KJ425241.1 \\
\hline 9 & 162 & Staphylococcus sp. ECBMB15 & 99 & KJ425241.1 \\
\hline 10 & 161 & Staphylococcus sp. ECBMB15 & 100 & KJ425241.1 \\
\hline
\end{tabular}

BLAST, Basic Local Alignment Search Tool. 
Table 5. Effect of diets on the level of intestinal permeability markers in plasma (Mean values with pooled standard errors; fifteen fish per diet)

\begin{tabular}{|c|c|c|c|c|c|c|}
\hline & $\mathrm{FM}$ & SBM $12.5 \%$ & SBM $25 \%$ & SBM $37.5 \%$ & SEM & $P$ \\
\hline \multicolumn{7}{|l|}{ Permeability markers } \\
\hline Endotoxin $(\mathrm{EU} / \mathrm{ml})$ & 0.09 & 0.08 & 0.09 & 0.08 & 0.019 & 0.621 \\
\hline DNA concentration $(\mu \mathrm{g} / \mathrm{ml})^{*}$ & $1 \cdot 30$ & 1.09 & $1 \cdot 14$ & 1.06 & 0.296 & 0.263 \\
\hline D-Lactate $(\mu \mathrm{g} / \mathrm{ml})$ & $6 \cdot 19^{b}$ & $7 \cdot 01^{b}$ & $6 \cdot 80^{\mathrm{b}}$ & $8.69^{a}$ & $1 \cdot 288$ & $<0.0001$ \\
\hline \multicolumn{7}{|l|}{ Sugar markers $(\mu \mathrm{g} / \mathrm{ml})$} \\
\hline Lactulose & $9 \cdot 20^{a, b}$ & $2 \cdot 00^{\mathrm{b}}$ & $2 \cdot 89^{b}$ & $10 \cdot 26^{\mathrm{a}}$ & 3.949 & 0.012 \\
\hline Sucralose & 0.71 & ND & ND & 1.19 & 0.951 & 0.421 \\
\hline L-Rhamnose & $15 \cdot 65^{a, b}$ & $17.09^{\mathrm{a}}$ & $14 \cdot 86^{a, b}$ & $10 \cdot 25^{\mathrm{b}}$ & 3.648 & 0.013 \\
\hline $\mathrm{L}: \mathrm{R} \dagger$ & $0.54^{a, b}$ & $0 \cdot 16^{\mathrm{b}}$ & $0.22^{\mathrm{b}}$ & $1.70^{\mathrm{a}}$ & 1.013 & 0.010 \\
\hline$S: R$ & 0.04 & ND & ND & 0.08 & 0.041 & 0.189 \\
\hline
\end{tabular}

FM, fish meal; SBM; soyabean meal; EU, endotoxin units; ND, not detected; L:R, lactulose:L-rhamnose ratio; S:R, sucralose:L-rhamnose ratio.

a,b Mean values within a row with unlike superscript letters were significantly different $(P<0.05)$.

* Genomic DNA measured after extraction.

† The Kruskal-Wallis test was performed for this parameter.

$37 \cdot 5 \%$ SBM, which may further indicate that rainbow trout seems to be less sensitive to SBM than Atlantic salmon ${ }^{(45)}$. A higher number of fish with SBMIE as a result of increased SBM inclusion is also consistent with previous reports ${ }^{(6)}$.

The relationship between gut barrier disturbance and the development of SBMIE is not yet known in fish. In this experiment, we hypothesised that SBMIE is associated with increased intestinal permeability which further promotes translocation of micro-organisms and/or their products into the bloodstream. In humans and mammals, bacterial translocation from the lumen into the circulation has been reported in subjects with intestinal inflammation ${ }^{(46,47)}$. Translocation of bacteria into the blood indicates a loss or impaired gut barrier function which may occur under different conditions. Under homeostatic conditions, some bacterial translocation may occur but is cleared by the organism's immune system ${ }^{(48)}$. The rate of normal bacterial translocation has been reported to be in the range of $5-10 \%$ in humans ${ }^{(49)}$ and $10-20 \%$ in animals ${ }^{(50)}$. When gut homeostasis is disturbed, however, a rise in the rate of bacterial translocation may occur ${ }^{(49)}$. In fish, the normal rate of bacterial translocation and its

Table 6. PCR results and plasma levels of intestinal permeability markers in soyabean meal (SBM)-induced enteritis (SBMIE) and non-SBMIE groups of rainbow trout (Oncorhynchus mykiss)

(Mean values with pooled standard errors)

\begin{tabular}{lcccc}
\hline Group & SBMIE $^{*}$ & Non-SBMIE & SEM & $P$ \\
\hline$n$ & 11 & 49 & & \\
PCR-positive samples & 3 & 4 & & \\
Genomic DNA $(\mu \mathrm{g} / \mathrm{ml})$ & 0.92 & 1.04 & 0.150 & 0.52 \\
Endotoxin $(\mathrm{EU} / \mathrm{ml})$ & 0.08 & 0.07 & 0.011 & 0.71 \\
Sugar markers $(\mu \mathrm{g} / \mathrm{ml})$ & & & & \\
$\quad$ L:R $\dagger$ & $1.06^{\mathrm{a}}$ & $0.47^{\mathrm{b}}$ & 0.325 & 0.02 \\
S:R & 0.08 & 0.04 & 0.031 & 0.23 \\
$\quad$ L-Rhamnose & $11.01^{\mathrm{b}}$ & $15.24^{\mathrm{a}}$ & 1.969 & 0.03 \\
$\quad$ D-Lactate & $8.91^{\mathrm{a}}$ & $6.77^{\mathrm{b}}$ & 0.490 & $<0.0001$ \\
\end{tabular}

EU, endotoxin units; L:R, lactulose:L-rhamnose ratio; S:R, sucralose:L-rhamnose ratio.

$\mathrm{a}, \mathrm{b}$ Mean values within a row with unlike superscript letters were significantly different $(P<0.05)$.

*Includes ten fish from the $37.5 \%$ SBM-fed group and one fish from the $25 \%$ SBM-fed group.

† The Kruskal-Wallis test was performed for this parameter. association with SBMIE is not known; however, there is evidence that gut bacteria translocate into enterocytes in larvae, fry and adult fish ${ }^{(51)}$. In this study, we used PCR-DGGE to detect and identify circulating bacterial DNA in fish. Our results indicate that the detection of bacterial DNA in plasma is more frequently associated with the incidence of SBMIE (OR 4.5) which may suggest a link between SBMIE and bacterial translocation. Disruption of the gut barrier has shown to be associated with bacterial translocation in a number of human studies ${ }^{(27,33,34)}$. The PCR-DGGE analyses in the present experiment identified several strains of two species of bacteria, Staphylococcus spp. and E. coli, and the latter has been known as a common translocating bacteria in humans ${ }^{(52)}$. Some strains of both E. coli and Staphylococcus spp. are known to cause infection, but PCR only detects bacterial DNA and does not differentiate between dead or living bacteria.

In this experiment, an increasing level of SBM inclusion and the occurrence of SBMIE did not increase plasma levels of endotoxins compared with FM-fed and non-SBMIE fish. The reason could be that endotoxins are cleared rapidly by the mucosal immune system, while trying to cross the epithelium under SBMIE.

Increased intestinal permeability, reflected by elevated urinary levels of sugar markers, has been reported in humans with impaired intestinal barrier integrity ${ }^{(17,18)}$. A high urinary or plasma L:R ratio is often used as an indication of small-intestinal hyperpermeability in mammals. Our results, however, do not show increased plasma L:R and S:R ratios as a result of increased SBM inclusion and revealed large variation among individuals in all dietary groups (Table 5). The L:R ratio was significantly increased in the SBMIE group, while the increase in the S:R ratio was not significant, presumably because of the small number of observations for sucralose $(n 6)$. The elevated L:R ratio in the SBMIE group is in accordance with previous findings in humans ${ }^{(18)}$ and may indicate that intestinal inflammation is associated with DI hyperpermeability; however, the variation was also found to be large for this parameter. Sugar markers were added to the diets; consequently, any variation in feed intake could reflect differences in the absorption of these molecules. Contrary to humans and model animals, the group feeding system is practised to feed the fish without monitoring the 
individual consumption of diets. Thus it is likely that individual fish used for plasma sugar analysis had consumed unequal amounts of these molecules before sampling. Based on these results, it seems that feed-added markers may not be suitable for the evaluation of intestinal permeability in fish that are group-fed. In this experiment, however, the SBMIE group had significantly lower plasma L-rhamnose levels which may be due to the epithelial changes as a result of SBMIE, with consequent adverse effect on L-rhamnose absorption. Most of the fish (ten of fifteen) from the group fed 37.5\% SBM had SBMIE which consequently resulted in a reduced mean of plasma L-rhamnose level in this group. A reduction in excretion levels of L-rhamnose as a result of increased gut permeability has been reported previously in human subjects ${ }^{(53)}$. The possible explanation is that the intestinal absorptive area may be reduced in response to inflammation which in turn can decrease the uptake of L-rhamnose into the bloodstream ${ }^{(54)}$.

Increased plasma levels of D-lactate have been shown in humans and model animals with intestinal barrier injury ${ }^{(55-57)}$. In fish with SBMIE, plasma D-lactate concentrations increased compared with the non-SBMIE fish, which suggests that increased intestinal permeability may have occurred as a result of inflammation. Furthermore, an increased degree of SBMIE showed a weak but significant correlation with plasma levels of D-lactate. This may suggest that other factors than SBMIE can also contribute to the increased plasma level of D-lactate. It has been shown, for example, that the increase in bacterial fermentation in the lumen as a result of bacterial overgrowth or carbohydrate malabsorption may also increase the level of D-lactate in the circulation independent of inflammation ${ }^{(58,59)}$. We also found a significant linear increase in plasma D-lactate as a result of increased SBM inclusion level, which raised the question whether there is a dietary effect on plasma D-lactate level independent of inflammation. However, we did not observe an increased D-lactate concentration in DI content from fish fed $37.5 \%$ SBM compared with the control group (data not shown), which may suggest that there is a relationship between SBMIE and increased gut permeability.

In conclusion, our results show that SBMIE resulted in increased plasma levels of D-lactate and an increased incidence of bacterial translocation. The plasma lactulose:L-rhamnose ratio was found to increase in fish with SBMIE; however, the analysis revealed a large variation among individuals, probably due to unequal feed consumption. This indicates that feed added markers are less reliable under the group-feeding strategy. Based on our results, D-lactate and PCR-based detection of bacteria are more suitable estimates for in vivo permeability assessment under SBMIE conditions in rainbow trout.

\section{Acknowledgements}

This study was supported by the Norwegian University of Life Sciences and Foods of Norway, a Centre for Research-based Innovation (the Research Council of Norway; grant no. 237841/030).

P. M.-T., M. Ø., J. W. S., A. J. R. and L. T. M. designed the experiment. P. M.-T. was involved in feed production, conducting the experiment, performing endotoxin and nested PCR analysis, statistical analysis and the writing of the manuscript. T. L. performed the histological evaluation. F. E. R. was involved in DGGE analysis and sequencing. J. W. A. performed high-performance anion exchange chromatography (HPAEC)based sugar analysis and L. T. M. performed the D-lactate analysis and with M. Ø. contributed to the writing of the manuscript. All authors contributed to and approved the manuscript.

The authors have no conflict of interest to declare.

\section{References}

1. Naylor R, Hardy R, Bureau D, et al. (2009) Feeding aquaculture in an era of finite resources. Proc Natl Acad Sci U S A 106, 15103 15110.

2. Gatlin DM, Barrows FT, Brown P, et al. (2007) Expanding the utilization of sustainable plant products in aquafeeds: a review. Aquacult Res 38, 551-579.

3. Francis G, Makkar HPS \& Becker K (2001) Antinutritional factors present in plant-derived alternate fish feed ingredients and their effects in fish. Aquaculture 199, 197-227.

4. Krogdahl $\AA$, Penn M, Thorsen J, et al. (2010) Important antinutrients in plant feedstuffs for aquaculture: an update on recent findings regarding responses in salmonids. Aquacult Res 41, 333-344.

5. Sahlmann C, Sutherland BJG, Kortner TM, et al. (2013) Early response of gene expression in the distal intestine of Atlantic salmon (Salmo salar L.) during the development of soybean meal induced enteritis. Fish Shellfish Immunol 34, 599-609.

6. Krogdahl A, Bakke-McKellep A \& Baeverfjord G (2003) Effects of graded levels of standard soybean meal on intestinal structure, mucosal enzyme activities, and pancreatic response in Atlantic salmon (Salmo salar L.). Aquacult Nutr 9, 361-371.

7. Baeverfjord G \& Krogdahl A (1996) Development and regression of soybean meal induced enteritis in Atlantic salmon, Salmo salar L., distal intestine: a comparison with the intestines of fasted fish.J Fish Dis 19, 375-387.

8. Penn MH, Bendiksen EÅ, Campbell P, et al. (2011) High level of dietary pea protein concentrate induces enteropathy in Atlantic salmon (Salmo salar L.). Aquaculture 310, 267-273.

9. Chikwati EM, Sahlmann C, Holm H, et al. (2013) Alterations in digestive enzyme activities during the development of diet-induced enteritis in Atlantic salmon, Salmo salar L. Aquaculture 402-403, 28-37.

10. Rogler G \& Rosano G (2014) The heart and the gut. Eur Heart J 35, 426-430.

11. Shen L, Su L \& Turner JR (2009) Mechanisms and functional implications of intestinal barrier defects. Dig Dis 27, 443-449.

12. Suzuki T (2013) Regulation of intestinal epithelial permeability by tight junctions. Cell Mol Life Sci 70, 631-659.

13. Arrieta MC, Bistritz L \& Meddings JB (2006) Alterations in intestinal permeability. Gut 55, 1512-1520.

14. Grootjans J, Thuijls G, Verdam F, et al. (2010) Non-invasive assessment of barrier integrity and function of the human gut. World $J$ Gastrointest Surg 2, 61-69.

15. Knudsen D, Jutfelt F, Sundh H, et al. (2008) Dietary soya saponins increase gut permeability and play a key role in the onset of soyabean-induced enteritis in Atlantic salmon (Salmo salar L.). Br J Nutr 100, 120-129.

16. Sanchez de Medina F, Romero-Calvo I, Mascaraque C, et al. (2014) Intestinal inflammation and mucosal barrier function. Inflamm Bowel Dis 20, 2394-2404.

17. Prager M, Durmus T, Buttner J, et al. (2014) Myosin IXb variants and their pivotal role in maintaining the intestinal barrier: a study in Crohn's disease. Scand J Gastroenterol 49, 1191-1200.

18. van Wijck K, Verlinden TJM, van Eijk HMH, et al. (2013) Novel multi-sugar assay for site-specific gastrointestinal permeability analysis: a randomized controlled crossover trial. Clin Nutr 32, 245-251.

19. DeMeo MT, Mutlu EA, Keshavarzian A, et al. (2002) Intestinal permeation and gastrointestinal disease. J Clin Gastroenterol 34, 385-396. 
20. Cox MA, Lewis KO \& Cooper BT (1999) Measurement of small intestinal permeability markers, lactulose, and mannitol in serum results in celiac disease. Dig Dis Sci 44, 402-406.

21. Mankertz J \& Schulzke JD (2007) Altered permeability in inflammatory bowel disease: pathophysiology and clinical implications. Curr Opin Gastroenterol 23, 379-383.

22. Redl H, Bahrami S, Schlag G, et al. (1993) Clinical detection of LPS and animal models of endotoxemia. Immunobiology 187, 330-345.

23. Guidet B, Barakett V, Vassal T, et al. (1994) Endotoxemia and bacteremia in patients with sepsis syndrome in the intensive care unit. Chest 106, 1194-1201.

24. Hurley JC (1995) Endotoxemia: methods of detection and clinical correlates. Clin Microbiol Rev 8, 268-292.

25. Jin W, Wang H, Ji Y, et al. (2008) Increased intestinal inflammatory response and gut barrier dysfunction in Nrf2-deficient mice after traumatic brain injury. Cytokine 44, 135-140.

26. Luan Z-G, Zhang H, Ma X-C, et al. (2010) Role of high-mobility group box 1 protein in the pathogenesis of intestinal barrier injury in rats with severe acute pancreatitis. Pancreas 39, 216-223.

27. Qiao Z, Li ZL, Li JY, et al. (2009) Bacterial translocation and change in intestinal permeability in patients after abdominal surgery. J Huą̧ong Univ Sci Tecbnolog Med Sci 29, 486-491.

28. Szalay L, Umar F, Khadem A, et al. (2003) Increased plasma D-lactate is associated with the severity of hemorrhagic/traumatic shock in rats. Shock 20, 245-250.

29. Wang LK, Wang LW, Li X, et al. (2013) Ethyl pyruvate prevents inflammatory factors release and decreases intestinal permeability in rats with D-galactosamine-induced acute liver failure. Hepatobiliary Pancreat Dis Int 12, 180-188.

30. Poeze M, Froon AHM, Greve JWM, et al. (1998) D-Lactate as an early marker of intestinal ischaemia after ruptured abdominal aortic aneurysm repair. BrJ Surg 85, 1221-1224.

31. Schoeffel U, Pelz K, Haring RU, et al. (2000) Inflammatory consequences of the translocation of bacteria and endotoxin to mesenteric lymph nodes. Am J Surg 180, 65-72.

32. Ammori BJ, Fitzgerald P, Hawkey P, et al. (2003) The early increase in intestinal permeability and systemic endotoxin exposure in patients with severe acute pancreatitis is not associated with systemic bacterial translocation: molecular investigation of microbial DNA in the blood. Pancreas 26, 18-22.

33. Frances R, Benlloch S, Zapater P, et al. (2004) A sequential study of serum bacterial DNA in patients with advanced cirrhosis and ascites. Hepatology 39, 484-491.

34. Kane TD, Alexander JW \& Johannigman JA (1998) The detection of microbial DNA in the blood: a sensitive method for diagnosing bacteremia and/or bacterial translocation in surgical patients. Ann Surg 227, 1-9.

35. Tipsmark CK \& Madsen SS (2012) Tricellulin, occludin and claudin-3 expression in salmon intestine and kidney during salinity adaptation. Comp Biochem Physiol Part A Mol Integr Physiol 162, $378-385$.

36. Syakuri H, Adamek M, Brogden G, et al. (2013) Intestinal barrier of carp (Cyprinus carpio L.) during a cyprinid herpes virus 3-infection: molecular identification and regulation of the mRNA expression of claudin encoding genes. Fish Shellfish Immunol 34, 305-314.

37. Olsen RE, Sundell K, Mayhew TM, et al. (2005) Acute stress alters intestinal function of rainbow trout, Oncorbynchus mykiss (Walbaum). Aquaculture 250, 480-495.

38. Sundh H, Kvamme BO, Fridell F, et al. (2010) Intestinal barrier function of Atlantic salmon (Salmo salar L.) post smolts is reduced by common sea cage environments and suggested as a possible physiological welfare indicator. BMC Pbysiol 10, 22.

39. Johnson IT, Gee JM, Price K, et al. (1986) Influence of saponins on gut permeability and active nutrient transport in vitro. J Nutr 116, $2270-2277$.
40. Merrifield DL, Dimitroglou A, Bradley G, et al. (2009) Soybean meal alters autochthonous microbial populations, microvilli morphology and compromises intestinal enterocyte integrity of rainbow trout, Oncorbynchus mykiss (Walbaum). J Fish Dis 32, 755-766.

41. Øverland M, Karlsson A, Mydland LT, et al. (2013) Evaluation of Candida utilis, Khyvveromyces marxianus and Saccharomyces cerevisiae yeasts as protein sources in diets for Atlantic salmon (Salmo salar). Aquaculture 402-403, 1-7.

42. Romarheim OH, Skrede A, Gao Y, et al. (2006) Comparison of white flakes and toasted soybean meal partly replacing fish meal as protein source in extruded feed for rainbow trout (Oncorbynchus mykiss). Aquaculture 256, 354-364.

43. Collins SA, Desai AR, Mansfield GS, et al. (2012) The effect of increasing inclusion rates of soybean, pea and canola meals and their protein concentrates on the growth of rainbow trout: concepts in diet formulation and experimental design for ingredient evaluation. Aquaculture 344-349, 90-99.

44. Heikkinen J, Vielma J, Kemiläinen O, et al. (2006) Effects of soybean meal based diet on growth performance, gut histopathology and intestinal microbiota of juvenile rainbow trout (Oncorbyncbus mykiss). Aquaculture 261, 259-268.

45. Refstie S, Korsøen ØJ, Storebakken T, et al. (2000) Differing nutritional responses to dietary soybean meal in rainbow trout (Oncorbynchus mykiss) and Atlantic salmon (Salmo salar). Aquaculture 190, 49-63.

46. Lee KK \& Yum KS (2012) Association of endotoxins and colon polyp: a case-control study. J Korean Med Sci 27, 1062-1065.

47. Guzman-de la Garza FJ, Ibarra-Hernandez JM, Cordero-Perez P, et al. (2013) Temporal relationship of serum markers and tissue damage during acute intestinal ischemia/reperfusion. Clinics 68, 1034-1038.

48. Sedman PC, Macfie J, Sagar P, et al. (1994) The prevalence of gut translocation in humans. Gastroenterology 107, 643-649.

49. Balzan S, De Almeida Quadros C, De Cleva R, et al. (2007) Bacterial translocation: overview of mechanisms and clinical impact. J Gastroenterol Hepatol 22, 464-471.

50. Berg RD \& Garlington AW (1979) Translocation of certain indigenous bacteria from the gastrointestinal tract to the mesenteric lymph nodes and other organs in a gnotobiotic mouse model. Infect Immun 23, 403-411.

51. Ringø E, Myklebust R, Mayhew TM, et al. (2007) Bacterial translocation and pathogenesis in the digestive tract of larvae and fry. Aquaculture 268, 251-264.

52. O'Boyle CJ, MacFie J, Mitchell CJ, et al. (1998) Microbiology of bacterial translocation in humans. Gut 42, 29-35.

53. Van Nieuwenhoven MA, Geerling BJ, Deutz NEP, et al. (1999) The sensitivity of the lactulose/rhamnose gut permeability test. Eur J Clin Invest 29, 160-165.

54. Bjarnason I, Macpherson A \& Hollander D (1995) Intestinal permeability: an overview. Gastroenterology 108, 1566-1581.

55. Sun XQ, Fu XB, Zhang R, et al. (2001) Relationship between plasma D-lactate and intestinal damage after severe injuries in rats. World J Gastroenterol 7, 555-558.

56. Assadian A, Assadian O, Senekowitsch C, et al. (2006) Plasma D-lactate as a potential early marker for colon ischaemia after open aortic reconstruction. Eur J V asc Endovasc Surg 31, 470-474.

57. Zhao Y, Qin G, Sun Z, et al. (2011) Effects of soybean agglutinin on intestinal barrier permeability and tight junction protein expression in weaned piglets. Int J Mol Sci 12, 8502-8512.

58. Dahhak S, Uhlen S, Mention K, et al. (2008) D-Lactic acidosis in a child with short bowel syndrome [article in French]. Arch Pediatr 15, 145-148.

59. Hove H \& Mortensen P (1995) Colonic lactate metabolism and D-lactic acidosis. Dig Dis Sci 40, 320-330. 